\title{
Keteladanan Guru Pendidikan Agama Islam Di Madrasah Aliyah Muhamammadiyah 1 Medan
}

\author{
Oleh: Dianto \\ Mahasiswa Pendidikan Agama Islam Pascasarjana UINSU Medan \\ (Email: diandianto23@yahoo.co.id)
}

\begin{abstract}
ABSTRAK
Penelitian ini dilaksanakan di Madrasah Aliyah Muhammadiyah 1 Medan dan bertujuan untuk mengetahui: 1) Keteladanan guru pendidikan agama Islam di Madrasah Aliyah Muhammadiyah 1 Medan. 2) Keteladanan guru pendidikan agama Islam dalam membina kedisiplinan siswa di Madrasah Aliyah Muhammadiyah 1 Medan. 3) Keteladanan guru pendidikan agama Islam dalam menumbuhkan minat belajar siswa di Madrasah Aliyah Muhammadiyah 1 Medan. 4) Pandangan dan pendapat siswa tentang keteladanan guru pendidikan agama Islam di Madrasah Aliyah Muhammadiyah 1 Medan.

Penelitian ini termasuk penelitian kualitatif. Pada umumnya alasan menggunakan metode kualititif karena permasalahan belum jelas, dinamis, dan penuh makna sehingga tidak mungkin data pada situasi sosial tersebut di jaring dengan metode penelitian kuantitatif. subyek dalam penelitian ini adalah empat guru pendidikan agama Islam yaitu guru mata pelajaran Alquran Hadist, Akidah Akhlak, Fiqih, dan Sejarah Kebudayaan Islam.

Hasil penelitian menemukan bahwa keteladanan guru sebagai orangtua di madrasah sangat berpengaruh dalam mendidik siswa agar bisa menjadi generasi yang beriman, bermoral dan berpendidikan. Guru pendidikan agama Islam sudah mempunyai sikap sopan santun, kedisplinan, berprestasi dan nilai-nilai ketaqwaan kepada Allah. Kemudian guru Agama Islam di Madrasah Aliyah Muhammadiyah 1 Medan juga mempunyai sifat kesabaran, wibawa, bersahabat, kerja keras, dan bertanggung jawab. Upaya guru di Madrasah Aliyah Muhammadiyah 1 Medan dalam menanamkan minat belajar dan kedispilinan siswa diawali dari guru itu sendiri sebagai suri tauladan bagi siswa, mulai dari kesabaran dan kesungguhan dalam mengajar.
\end{abstract}

Kata kunci: Keteladanan guru, kedisiplinan dan minat belajar.

\section{A. PENDAHULUAN}

\subsection{Latar Belakang Masalah}

Dalam dunia pendidikan, setiap guru mempunyai tujuan yang harus tercapai dalam mendidik siswanya, seperti mempunyai ilmu pengetahuan, berakhlak mulia dan bisa mencerdaskan generasi anak bangsa. Beberapa tujuan di atas tidak akan bisa tercapai jika seorang pendidik tidak mempunyai ilmu dan akhlak yang baik dalam mengajar di sekolah. Hal ini membuktikan bahwa cerdasnya anak 
bangsa tergantung kepada guru yang mendidiknya.

Salah satu komponen penting dalam pendidikan adalah guru. Guru dalam konteks pendidikan mempunyai peranan yang besar dan strategis. Hal ini disebabkan gurulah yang berada di barisan terdepan dalam pelaksanaan pendidikan. Gurulah yang langsung berhadapan dengan peserta didik untuk menstransfer ilmu pengetahuan dan teknologi sekaligus mendidik dengan nilai-nilai positif melalui bimbingan dan keteladanan.

Kemudian guru hendaknya menjadi garda (garis depan), memberi contoh, menjadi motivator, dalam penanaman budi pekerti. Sering ada pepatah yang menyinggung pribadi guru, yaitu sebagai figure yang harus di comtoh dan ditiru. Inilah figure ideal yang didambakan setiap bangsa. Figur inilah yang menghendaki seorang guru perlu menjadi suri tauladan dalam aplikasi pendidikan budi pekerti. ${ }^{1}$

Disamping itu, pendidikan adalah investasi sumber daya manusia jangka panjang yang mempunyai nilai strategis bagi kelangsungan peradaban manusia di dunia.Maka, semua negara

\footnotetext{
${ }^{1}$ Rahmat Muhammad, Sofan Amri, Kode Etik Profesi Guru, (Jakarta: Prestasi Pustaka, 2014), h. 179.
}

menempatkan variabel pendidikan sebagai sesuatu yang penting dan utama dalam konteks pembangunan bangsa dan negara. ${ }^{2}$ Begitu juga Indonesia menempatkan pendidikan sebagai sesuatu yang penting dan utama. Hal ini dapat dilihat dari isi pembukaan UUD 1945 alinea IV yang menegaskan bahwa salah satu tujuan nasional bangsa Indonesia adalah mencerdaskan kehidupan bangsa.

Dengan demikian, pentingnya memberikan pendidikan kepada anak terutama pendidikan moral yang didasarkan pada ajaran agama Islam. Anak adalah penerus keturunan, penerus agama, bangsa dan negara maka bekalilah mereka dengan ilmu pengetahuan, keterampilan serta keimanan agama, agar bangsa dan negara serta keturunan selamat dan terhindar dari gangguan-gangguan yang dapat merusak keberadaannya. ${ }^{3}$ Oleh karena itu, diperlukan suatu sistem, agar anak dapat tumbuh dengan bekal pengetahuan, keterampilan serta keimanan dan ketaqwaan kepada Allah swt.

${ }^{2}$ Indra Ahmad Wijaya, Guru dan Orangtua Sebagai Pendidik, (Jakarta: Cita Pustaka, 2000), h. 56.

${ }^{3} \mathrm{Ibid}, 60$. 
Beranjak dari uraian di atas, yang menjadi latar belakang masalah penelitian ini adalah:

1. Guru adalah sosok yang diteladani, dan karena keteladanannya itu, gerak-gerik seorang guru senantiasa diperhatikan oleh masyarakat.

2. Pada umumnya peserta didik lebih suka mengikuti apa yang dilihat dari apa yang di dengarnya, anak-anak lebih suka mengikut apa yang dikerjakan dari pada mematuhi apa yang disuruh.

Berdasarkan latar belakang di atas, penulis mengambil penelitian yang berjudul: "Keteladanan Guru Pendidikan Agama Islam Di Madrasah Aliyah Muhammadiyah 1 Medan".

\subsection{Identifikasi Masalah}

Berdasarkan uraian di atas, dapatlah diidentifikasi beberapa hal yang menjadi permasalahan pokok, yaitu:

1. Keteladanan guru pendidikan agama Islam belum diterapkan oleh siswa dalam kegiatan pembelajaran di sekolah.

2. Beberapa guru pendidikan agama Islam belum sepenuhnya mempunyai keteladanan yang baik terhadap siswa.

3. Masih banyak siswa yang tidak disiplin dalam kehadiran dan dalam kegiatan pembelajaran di sekolah.

4. Rendahnya minat belajar siswa dalam pembelajaran pendidikan agama Islam.

\subsection{Rumusan Masalah}

1. Bagaimanakah keteladanan guru pendidikan agama Islam di Madrasah Aliyah Muhammadiyah 1 Medan?

2. Bagaimanakah keteladanan guru pendidikan agama Islam dalam membina kedisiplinan siswa di Madrasah Aliyah Muhammadiyah 1 Medan?

3. Bagaimanakah keteladanan guru pendidikan agama Islam dalam menumbuhkan minat belajar siswa di Madrasah Aliyah Muhammadiyah 1 Medan?

4. Bagaimana pandangan siswa tentang keteladan guru pendidikan agama Islam di Madrasah Aliyah Muhammadiyah 1 Medan?

\subsection{Tujuan Penelitian}


Dari rumusan masalah di atas, maka penulis bertujuan untuk mengetahui:

1. Keteladanan guru pendidikan agama Islam di Madrasah Aliyah Muhammadiyah 1 Medan.

2. Keteladanan guru pendidikan agama Islam dalam membina kedisiplinan siswa di Madrasah Aliyah Muhammadiyah 1 Medan.

3. Keteladanan guru pendidikan agama Islam dalam menumbuhkan minat belajar siswa di Madrasah Aliyah Muhammadiyah 1 Medan.

4. Pandangan dan pendapat siswa tentang keteladanan guru pendidikan Agama Islam di Madrasah Aliyah Muhammadiyah 1 Medan.

\subsection{Manfaat Penelitian}

Dari penelitian ini diharapkan dapat memberikan informasi yang jelas tentang keteladanan guru pendidikan agama Islam dalam meningkatkan kedisiplinan dan minat belajar siswa dan dari penelitian ini diharapkan dapat memberikan manfaat secara praktis dan teoritis.

1. Secara Teoritis.

Penelitian ini di harapkan dapat memberikan sumbangan atau masukan bagi dunia pendidikan khususnya di
Madrasah Aliyah Muhammadiyah 1 Medan yang dijadikan sebagai tempat penelitian.

2. Secara Praktis.

a. Bagi Siswa

- Menjadikan siswa semakin beriman, bermoral dan berpendidikan.

- Agar siswa mempunyai masa depan yang lebih baik dan bisa membahagiakan kedua orang tuanya.

- Siswa dapat aktif untuk terus belajar dan mempunyai ilmu pengetahuan yang bermanfaat.

- Siswa dapat meninggalkan perbuatan yang tercela dan tidak tejerumus kedalam pergaulan bebas.

b. Bagi Guru

- Meningkatkan kualitas mengajar guru pendidikan agama Islam dalam membimbing dan membina siswa agar menjadi lebih baik lagi.

- Guru bisa menjadi suri tauladan yang baik dalam mengajar dan mendidik siswa.

- Sebagai bahan masukan guru pendidikan agama Islam agar 
mempunyai keteladan yang baik dalam mendidik siswa.

c. Bagi Madrasah

- Sebagai bahan masukan untuk menambah wawasan dan ilmu pengetahuan tentang pentingnya keteladanan guru pendidikan agama Islam maupun guru bidang studi yang lain dalam membina kedisiplinan dan minat belajar siswa.

- Sebagai bahan pertimbangan bagi peneliti berikutnya, yang berminat melakukan penelitian sejenis.

\section{B. Kajian Pustaka}

\subsection{Keteladanan Guru}

\subsubsection{Pengertian Keteladanan Guru}

Berbicara tentang sosok guru yang ideal dalam Islam, segera muncul dalam benak umat Islam sosok manusia dan pendidik teladan. Nabi Muhammad Saw adalah teladan bagi semua orang, baik untuk si kaya maupun si miskin, berkedudukan maupun orang biasa, tua maupun muda, dan laki-laki maupun perempuan. Keagungan pribadi
Muhammad diabadikan dalam Alquran berupa pujian Allah dalam firmanya:

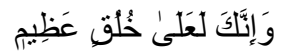

Artinya: "Dan sesungguhnya kamu benar-benar berbudi pekerti yang agung." 4

Dalam ayat lain Allah berfirman dalam bentuk kalimat yang berisi perintah untuk meneladani Rasulullah saw yaitu yang berbunyi:

1

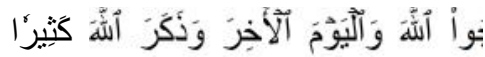

Artinya: "Sesungguhnya telah ada pada (diri) Rasulullah itu suri teladan yang baik bagimu (yaitu) bagi orang yang mengharap (rahmat) Allah dan (kedatangan) hari kiamat dan dia banyak menyebut Allah." 5

Kemudian dalam Kamus Besar Bahasa Indonesia disebutkan bahwa "keteladanan" adalah kata dasar dari keteladanan ialah "teladan" yang artinya perbuatan atau barang dan sebagainya yang patut ditiru atau dicontoh. Dalam bahasa Arab "keteladanan" diungkapkan dengan 
kata "uswah" dan "qudwah". Kata "uswah" terbentuk dari huruf-huruf hamzah, as-sin, dan al-waw.

Secara etimologi, setiap kata bahasa Arab yang terbentuk dari ketiga huruf tersebut memiliki persamaan arti yaitu pengobatan dan perbaikan. Namun keteladanan yang dimaksud disini adalah keteladanan yang dapat dijadikan sebagai alat pendidikan Islam yaitu keteladanan yang baik sesuai dengan pengertian "uswah". 6 Keteladanan guru juga diartikan sebagai guru yang berprestasi, menguasai materi, metodelogi dan terampil dalam mengajar yang didukung dengan komitmen serta dedikasi yang tinggi sehingga mampu menjalankan tugas dengan tekun dan disiplin. $^{7}$

Dari berbagai pandangan diatas, penulis berpendapat bahwa keteladanan guru adalah perbuatan baik yang dilakukan oleh guru, seperti sopan santun, disiplin, berprestasi dan mencerminkan ketaqwaan kepada Allah swt. Keteladanan guru inilah yang harus dimiliki oleh setiap guru

\footnotetext{
${ }^{6}$ Armai Arief, Pengantar Ilmu dan Metodologi Pendidikan Islam, (Jakarta : Jakarta Pers. 2002), h. 117.

${ }^{7}$ Tobroni, Pendidikan Islam Paradigma Teologis Filosofis dan Spritualitas, (Malang: UMM Pers, 2008), h. 192.
}

agar bisa mendidik dengan baik sehingga bisa menjadikan anak bangsa yang beriman, bermoral dan berpendidikan.

\subsubsection{Sifat-sifat Guru Teladan}

Agar dapat melaksanakan tugas dan kewajiban guru dengan baik, maka ada beberapa sifat yang harus dimiliki oleh guru teladan, yaitu :

1. Bersifat zuhud, dalam arti tidak mengutamakan kepentingan materi dalam pelaksanaan tugasnya, namun lebih mementingkan perolehan keridhaan Allah.

2. Berjiwa bersih dan terhindar dari sifat buruk, dalam arti bersih secara fisik dan jasmani.

3. Bersikap ikhlas dalam melaksanakan tugas mendidik.

4. Bersifat pemaaf, peserta didik sebagai manusia berpotensi tentu penuh dinamika

5. Bersifat kebapaan, dalam arti ia harus memposisikan diri sebagai pelindung yang mencintai muridnya serta mendukung masa depan mereka.

6. Mampu memahami bakat, tabiat dan watak peserta didik.

\footnotetext{
${ }^{8}$ Armai Arief, Pengantar Ilmu...”, h. 36-38.
} 


\subsubsection{Cara Mengungkapkan \\ Keteladanan Guru}

Paul Suparno menjelaskan ada beberapa cara guru untuk mengungkapkan keteladanan yang baik bagi siswa antara lain sebagai berikut: ${ }^{9}$

a. Konsekuen dengan yang diajarkan

b. Tidak main topeng

c. Kembangkan ilmu pengetahuan

Kemudian Hasan Aedy berpendapat bahwa untuk menjadi teladan bagi siswa ada beberapa hal yang harus dilakukan oleh guru yaitu: 10

a. Meningkatkan ketaqwaan dan akhlak mulia

b. Menjalin hubungan yang harmonis

Dari uraian di atas, dapat disimpulkan bahwa untuk menjadi teladan yang baik, banyak hal-hal yang perlu dilakukan oleh guru di hadapan siswa. Guru dapat mengungkapkannya dalam berbagai cara sebagai berikut ini:

1. Guru harus konsekuen dengan yang diajarkan.

2. Guru harus mengembangkan ilmu pengetahuan.

\footnotetext{
${ }^{9}$ Paul Suparno, Guru Demokratis di Era Demokrasi,..." h. 69-70.

${ }^{10}$ Hasan Aedy, Karya Agung Sang Guru Sejati, ( Bandung: Alfabeta, 2005), h. 105-106.
}

3. Guru perlu menampilkan hal-hal baik.

\subsection{Kedisiplinan}

\subsubsection{Pengertian Disiplin}

Disiplin merupakan istilah yang sudah memasyarakat diberbagai instansi pemerintah maupun swasta. Kita mengenal adanya disiplin kerja, disiplin lalu lintas, disiplin belajar dan macam istilah disiplin yang lain. Disiplin secara etimologi berasal dari bahasa latin "disibel" yang berarti pengikut. Seiring dengan perkembangan bahasa, kata tersebut mengalami perubahan menjadi 'disipline” yang artinya kepatuhan atau yang menyangkut tata tertib.

\subsubsection{Pentingnya Kedisplinan}

Steve Chalke berpendapat bahwa pentingnya menerapkan disiplin pada anak adalah: ${ }^{11}$

a. Disiplin dapat menjadi kerangka dan keberanian yang diciptakan oleh orang tua untuk membantu anak mengetahui bagaimana mengontrol perilaku dan mengembangkan disiplin diri.

b. Disiplin dapat menjadi daya picu untuk membangun kematangan

\footnotetext{
${ }^{11}$ Steve Chalke. Kiat-Kiat Menjadi Orangtua Teladan, (Yogyakarta: Inspirasi Buku Utama, 2005), h. 100.
} 
dan konsistensi dan membantu anak menyesuaikan diri dengan masyarakat tanpa ada yang mempengaruhinya.

Dari penjelasan di atas, dapat disimpulkan bahwa disiplin sangat penting bagi pertumbuhan anak karena tumbuh kembang anak tidak hanya secara fisik tetapi juga secara mental dan sosial.

\section{Metode Penelitian}

\subsection{Lokasi dan Waktu Penelitian}

Penelitian ini di laksanakan di Madrasah Aliyah Muhammadiyah 1 Medan yang beralamat di jalan Mandala By Pass No. 140-a kode pos 20224 Kec. Medan Tembung. Pemilihan tempat ini berdasarkan atas pertimbangan kemudahan dalam memperoleh data sesuai dengan kemampuan baik dari segi waktu dan juga keterbatasan dana.

Penelitian ini dilakukan dalam dua tahap, dimana tahap pertama peneliti lakukan untuk membuat proposal dan memohon izin secara lisan kepada pihak sekolah yang peneliti lakukan pada bulan Desember 2017. Penelitian kedua adalah penelitian inti untuk melihat keteladanan guru di Madrasah Aliyah Muhammadiyah 1 Medan.

\subsection{Metode Penelitian}

Jenis penelitian ini adalah penelitian kualitatif. Pada umumnya alasan menggunakan metode kualitatif karena permasalahan belum jelas, dinamis, dan penuh makna sehingga tidak mungkin data pada situasi sosial tersebut di jaring dengan metode penelitian kuantitatif.

\subsection{Subyek Penelitian}

Subjek adalah keseluruhan objek penelitian. Sedangkan subyek penelitian menunjuk pada orang atau individu atau kelompok yang dijadikan unit atau satuan yang diteliti. Jadi, subyek dalam penelitian ini adalah empat guru agama Islam yaitu guru mata pelajaran Alquran Hadis, Akidah Akhlak, Fiqih, dan Sejarah Kebudayaan Islam serta siswa-siswi kelas X.1 ada enam orang, kelas X.2 ada delapan orang, kelas XI IPA ada dua orang, dan kelas XI IPS ada tiga orang. Sedangkan dikelas XII tidak dijadikan sebagai subjek dikarena sebagian guru tidak masuk mengajar lagi dan mereka difokuskan agar bisa menjalankan ujian sekolah, praktek dan UN dengan maksimal.

\subsection{Data dan Sumber Data}

Sumber data dalam penelitian ini adalah kepala sekolah, wakil 
kepala sekolah, dan guru-guru, serta segenap unsur pendidikan yang berada di Madrasah Aliyah Muhammadiyah 1 Medan. Data-data yang peneliti peroleh dari sumber data tersebut peneliti bedakan pada:

1. Data Primer: Melakukan observasi dikelas dan wawancara dengan empat guru agama Islam yaitu guru mata pelajaran Alquran Hadis, Akidah Akhlak, Fiqih, dan Sejarah Kebudayaan Islam.

2. Data Skunder: Berasal dari daftar absen kehadiran guru, angket intrumen kinerja guru dan sebagainya.

\subsection{Instrumen Penelitian}

Dalam peneltian kualitatif, yang menjadi intrumen atau alat penelitian adalah peneliti itu sendiri. Adapun yang dilakukan saat penelitian dilaksanakan yaitu observasi dikelas dengan melihat keteladanan guru sesuai dengan indikatornya seperti dibawah ini:

\section{Guru yang sopan santun}

Guru yang sopan santun terdiri dari akhlak yang mulia dan perkataan yang baik. Untuk menilai akhlak mulia dilihat dari:

a. Bagaimana cara guru masuk kedalam ruangan kelas. b. Berdo'a sebelum belajar dan selesai belajar, apakah dilaksanakan dalam pembelajaran?

c. Apakah memiliki sikap lemah lembut?

d. Apakah berpakaian yang rapi dan tidak memperlihatkan aurat?

Untuk menilai perkataan yang baik dilihat dari:

a. Kejujuran saat menyampaikan materi pembelajaran

b. Tidak mengucapkan kata kasar seperti hinaan terhadap siswa.

2. Guru yang disiplin

Guru yang disiplin terdiri dari kehadiran datang kesekolah, seperti:

a. Kehadiran guru datang kesekolah.

b. Kehadiran guru saat mulai jam pembelajaran.

3. Guru berprestasi

Guru berprestasi dilihat dari:

a. Mempunyai bakat dan keahlian yang bisa memberikan motivasi kepada orang lain.

b. Mempunyai sikap mengajar yang baik, seperti kejujuran dan kesungguhan.

c. Mempunyai rasa tanggungjawab dalam mendidik.

4. Guru yang bertaqwa 


\begin{abstract}
Guru teladan harus mencerminkan ketaqwaan kepada Allah. Ketaqwaan terdiri dari shalat, puasa, bersedekah, dan amal soleh lainnya. Untuk menilai ketaqwaan guru bisa dilihat saat disekolah seperti:
\end{abstract}

a. Tiba waktu shalat dhuha, shalat dzuhur dan shalat ashar. Apakah guru menjalankannya?

b. Berpuasa sunnah pada hari senin dan kamis.

c. Bersedekah, misalnya ada sumbangan dana untuk orang tua yang meninggal dunia atau anak murid yang sakit. Apakah guru memberikan sedekah?

\subsection{Teknik Pengumpulan Data}

Metode pengumpulan data dilakukan peneliti melalui tiga cara yaitu wawancara, observasi dan dokumentasi.

\section{Wawancara}

Metode wawancara adalah sebuah dialog yang dilakukan oleh pewawancara (interviewer) untuk memperoleh informasi dari yang terwawancara.

2. Observasi Participant

Observasi atau pengamatan adalah kegiatan sesorang untuk mengetahui suatu informasi dengan menggunakan pancaindera mata sebagai alat bantu utamanya, yang disempurnakan dengan pancaindera lainnya.

3. Dokumentasi

Dokumentasi adalah mencari data mengenai hal berupa catatan, buku, notulen rapat, agenda, dan raport siswa.

\subsection{Teknik Analisa} Data

Metode analisis data yang digunakan adalah analisis data yang bersifat kualitatif dengan deskriptif analitik. Menurut Miles and Hubermas, mengemukakan bahwa aktivitas dalam analisis data kualitatif dilakukan secara interaktif dan berlangsung secara terus menerus sampai tuntas, sehingga datanya sudah jenuh. Aktivitas dalam analisis data yaitu data reduction, data display dan conclusion drawing/verification. ${ }^{12}$

\subsection{Prosedur Penelitian}

Untuk memperoleh informasi, peneliti menggunakan wawancara. Dengan demikian, agar peneliti dapat melaksanakan penelitian ini dengan

\footnotetext{
${ }^{12}$ Sugiyono, Metode Penelitian...., h.
} 337. 
lancar, serta dapat memperoleh data yang diinginkan, peneliti mengitu prosedur berikut ini:

1. Tahap Persiapan

Dalam tahap ini, peneliti melakukan beberapa kegiatan, yaitu: peneliti mengajukan judul tesis penelitian kepada ketua program studi pendidikan, kemudian mengurus surat izin penelitian.

2. Tahap Pelaksanaan

Mengumpulkan data dengan wawancara, observasi dan dokumentasi. Mengidentifikasi dari metode di atas secara kronologis dan sistematis, pengelolahan data dan menganalisa data.

3. Tahap penyusunan laporan hasil penelitian

Yaitu dengan melakukan penelitian, mencatat semua hasil penelitian, menganalisis hasil penelitian dan yang terakhir membuat laporan hasil penelitian dalam berbagai bentuk.

\section{Hasil dan Pembahasan Penelitian}

\subsection{Hasil Penelitian}

\subsubsection{Keteladanan guru pendidikan agama} Islam pada mata pelajaran Alquran Hadist.

Berbicara tentang ketaladan guru pendidikan agama Islam, bapak Syarif Sarto mengatakan bahwa seorang guru harus mempunyai tutur kata yang baik, berperilaku yang baik terutama dalam beribadah kepada Allah. Misalnya ketika guru menyuruh siswanya untuk disiplin tepat waktu pada saat datang kesekolah dan waktu jam belajar, maka terlebih dahulu guru harus mencontohkan kedisplinan tersebut. ${ }^{13}$

$$
\text { Kedispilinan guru mata }
$$

pelajaran Alquran Hadist, sangat memberikan keteladanan yang baik, misalnya mulai dari kehadiran datang ke sekolah tidak pernah terlambat dan masuk kedalam kelas selalu tepat waktu.

Setelah melakukan wawancara lebih mendalam lagi, ternyata guru mata pelajaran Alquran Hadist mempunyai prestasi yang sangat bagus dan bisa memberikan motivasi

\footnotetext{
${ }^{1}$ Wawancara dengan Bapak Sarto Syarif, Lc. (guru mata pelajaran Alquran Hadis). Di ruang guru pada hari Rabu tanggal 08 Februari 2017 jam 09.00 wib s/d selesai.
} 
terhadap anak didiknya. Prestasi tersebut yaitu mendapatkan gelar sarjana di mesir, gelar magister di UIN Medan dan saat ini beliau sedang menyelesaikan program doctor di UIN Medan.

Setelah melakukan penelitian secara keselurahan, maka dapat dijelaskan bahwa guru mata pelajaran Alquran Hadist termasuk guru yang rajin beribadah kepada Allah, mulai dari shalatnya selalu lima waktu dan senantiasa meningkatkan amal soleh.

\subsubsection{Keteladanan guru pendidikan} agama Islam pada mata pelajaran Akidah Akhlak.

Di Madrasah Aliyah

Muhammadiyah 1 Medan dapat dijelaskan bahwa guru mata pelajaran Akidah Akhlak sangat mempunyai keteladanan yang baik terhadap siswanya. Pada saat wawancara dengan bapak Muhammad Syahri, S.Ag tentang keteladan guru beliau menjelaskan bahwa guru teladan merupakan suatu kehormatan yang diberikan kepada siswa, kepala sekolah dan pimpinan yayasan sekolah. Guru bisa dikatakan sebagai teladan jika ia mempunyai sikap kehadiran tepat waktu, diidolakan anak-anak saat menyampaikan jam belajar, dan bisa membimbing siswa dengan baik. ${ }^{14}$

Dalam penelitian yang dilakukan di Madrasah Aliyah Muhammadiyah 1 Medan, guru akidah akhlak mempunyai sikap sopan santun yang sangat mulia. Misalnya saat mengajar, guru tersebut berkata yang baik dan selalu memberikan motivasi dalam pembelajaran yang dilakukannya. Disamping itu guru mata pelajaran Akidah Akhlak selalu berpakaian yang rapi sehingga bisa memberikan contoh yang baik kepada siswanya.

Kedisiplinan guru mata pelajaran Akidah Akhlak juga mempunyai cerminan dan sikap yang baik. Bisa dilihat dari kehadiran beliau selalu datang tepat waktu untuk mengajar. Dengan Maka setelah melakukan peneliti yang lebih lanjut lagi, dapat dijelaskan bahwa guru mata pelajaran Akidah Akhlak sangat istiqomah dalam menjalankan ibadah shalat dan senantiasa menjalankan amalan soleh lainnya.

14 Wawancara dengan Bapak Muhammad Syahri, S.Ag. (guru mata pelajaran Akidah Akhlak). Di ruang guru pada hari sabtu tanggal 11Februari 2017jam 09.00 wib s/d selesai. 
3.1.3. Keteladanan guru pendidikan agama Islam pada mata pelajaran Fiqih.

Berbicara tentang pengertian keteladan guru, Ibu susianti mengatakan bahwa guru teladan adalah guru yang memberikan contoh baik kepada siswanya. Kemudian guru teladan adalah guru yang bisa membimbing, mengarahkan siswa dalam perbuatan baik sehingga bisa menjadikan siswa mempunyai aklak yang terpuji, dan guru teladan harus bisa memberikan motivasi siswa untuk terus belajar sehingga mereka bisa meraih cita-citanya. ${ }^{15}$

Setelah diteliti lebih lanjut lagi, dapat dijelaskan bahwa guru Fiqih mempunyai sopan santun yang sangat baik. Misalnya saat ia datang kesekolah pasti selalu berpakaian yang rapi dan menutup auratnya. Cara mengajar dalam pembelajaran juga mempunyai bahasa yang santun dan mudah dipahami oleh siswanya.

Kedisplinan juga sangat diterapkan oleh siswanya, seperti kehadiran tepat waktu datang kesekolah dan ketepatan waktu saat

15 Wawancara dengan Ibu Susianti, MA (guru mata pelajaran Fiqih). Di ruang guru pada hari Kamis tanggal 09 Februari 2017 jam 09.00 wib s/d selesai. masuk jam belajar. Dengan adanya kedisiplinan yang dimiliki oleh guru Fiqih bisa menjadikan siswa tersebut lebih aktif dan mempunyai semangat belajar yang tinggi dalam mempelajari ilmu agama Islam.

Alhamdulillah setelah diteliti kembali, guru tersebut sangat rajin menjalankan ibadah shalat sunnah dhuha, shalat dzuhur dan shalat ashar disekolah dengan berjama'ah dan selalu meningkatkan amal soleh lainnya.

\subsubsection{Keteladanan guru pendidikan agama Islam pada mata pelajaran Sejarah \\ Kebudayaan Islam.}

Berbicara tentang keteladanan, Ibu Ernani mengatakan bahwa guru teladan adalah guru yang bisa membimbing siswanya dengan baik. Misalnya memberikan contoh sikap yang mulia dalam mengajar dan nasihat yang baik agar siswa semangat untuk belajar. Guru teladan juga harus bisa bersikap tegas terhadap siswa yang malas belajar dengan memberikan hukuman yang bisa membuat siswa menjadi semangat untuk belajar. Contohnya seperti menghafal Alquran maupun hadist 
yang bisa membuat siswa tersebut menjadi baik dan berakhlak mulia. ${ }^{16}$

Dalam penelitian yang dilakukan saat jam mengajar, dapat dijelaskan bahwa guru teladan sudah bersikap sopan santun terhadap siswanya. Sikap sopan santun ini muncul saat guru memberikan materi pembelajaran di dalam kelas. Guru selalu berkata yang baik sehingga siswa tersebut mudah memahami setiapmateri yang diajarkannya. Saat mengajar guru tersebut juga berpakaian muslimah sehingga bisa memberikan contoh yang baik dalam menjaga aurat terutama bagi kaum wanita.

Keteladan guru mata pelajaran Sejarah Kebudayaan Islam juga terlihat dari kedisplinan saat hadir kesekolah. Beliau selalu tepat waktu datang pagipagi sehingga kegiatan jam belajar bisa berjalan dengan baik. Ibu Ernani merupakan kepala madrasah yang berprestasi dalam dunia pendidikan, ia mempunyai banyak bakat dan kemampuan yang dimilikinya sehingga bisa menjadikan dirinya sebagai kepala

${ }^{16}$ Wawancara dengan Ibu Ernani, MA (Kepala MAM 1 Medan dan guru mata pelajaran Akidah Akhlak). Di ruangan kepala sekolah pada hari sabtu tanggal 18Februari 2017 jam 09.00 wib s/d selesai. madrasah di Madrasah Aliyah Muhammadiyah 1 Medan.

Peneliti juga menjelaskan bahwa guru Sejarah Kebudayaan Islam sudah mencerminkan sikap ketaqwaan kepada Allah.Karena beliau sering menjalankan shalat berjama'ah dzuhur dan ashar dimasjid.

\section{E. Kesimpulan dan Saran 5.1. Kesimpulan}

Hasil penelitian yang telah diuraikan di atas beserta pembahasannya ditemukan beberapa kesimpulan sebagai berikut:

1. Keteladanan guru sebagai orangtua di madrasah sangat berpengaruh dalam mendidik siswa agar bisa menjadi generasi yang beriman, bermoral dan berpendidikan. Hal-hal yang menjadi teladan siswa terhadap guru adalah sopan santun, kedisplinan, prestasi dan nilai-nilai ketqwaan kepada Allah.

2. Upaya guru di Madsrah Aliyah Muhammadiyah 1 Medan dalam menanamkan kedispilinan siswa diawali dari guru itu sendiri sebagai 


\begin{abstract}
suri tauladan bagi siswa, mulai dari kesabaran, kesungguhan mengajar dan mengetahui kewajiban sebagai seorang pendidik, seperti menjadi tauladan bagi siswa, perhatian yang besar terhadap siswa, bersikap sopan santun terhadap siswa, memberikan contoh yang baik, menanamkan nilai-nilai keislaman dan kebangsaan bagi siswa melalui materi pelajaran, dan mendidik siswa secara fleksibel.
\end{abstract}

\subsection{Saran-saran}

Mengingat pentingnya keteladanan guru dalam meningkatkan minat belajar dan kesipilinan bagi siswa di Madrasah Aliyah Muhammadiyah 1 Medan, maka di harapkan guru dan tenaga kependidikan di lembaga ini serta lembaga pendidikan lainnya, hendaknya melaksanakan upaya-upaya yang telah ada secara terarah, terpadu dan terprogram baik bagi instansi, dan guru secara bersama-sama. Oleh sebab itu, saran-saran yang dapat peneliti tuangkan dalam penelitian ini diantaranya:

\section{Bagi Guru}

- Guru diharapkan dapat meningkatkan teladan yang baik pada siswa khususnya dalam hal berperilaku. Keteladanan ini bisa ditunjukkan dengan cara berperilaku sopan pada semua pihak, tekun dalam menjalankan tugas, selalu terbuka, mampu menjalin kerjasama dengan pihak lain, dan menjalin hubungan yang harmonis dengan orang lain khususnya pada siswa. Dengan memberikan contoh perilaku yang baik, maka akan berdampak baik juga pada perilaku siswa.

- Setiap guru agama Islam sebaiknya mampu mengimplementasikan

nilai-nilai keislaman yang terkandung dalam materi pembelajaran dalam meningkatkan minat belajar dan kedisiplinan siswa.

- Guru pendidikan agama Islam harus membimbing siswa dengan baik, misalnya memerintahkan siswa agar rajin 


$$
\begin{aligned}
& \text { menjalankan shalat lima } \\
& \text { waktu dengan berjama'ah, } \\
& \text { membaca } \\
& \text { bersedekah, } \\
& \text { melaksanakan amal soleh } \\
& \text { lainnya. }
\end{aligned}
$$

\section{Bagi Siswa}

- Melalui keteladanan guru di harapkan peserta didik di Madrasah

Aliyah

Muhammadiyah 1 Medan

bisa meningkatkan

kedisplinan dan minat

belajar siswa. Kemudian

diharapkan siswa bisa menjadi generasi penurus bangsa yang beriman, berakhlak mulia dan berpendidikan sehingga mereka bisa membahagiakan kedua orang tuanya.

3. Bagi Madrasah

- Agar madrasah semakin maju dan berkembang, terutama dalam dunia pendidikan sehingga bisa mewujudkan generasi masa depan yang berilmu, bermoral dan beriman.

- Sebagai bahan masukan untuk menambah wawasan dan ilmu pengetahuan tentang pentingnya keteladanan guru pendidikan agama Islam maupun guru bidang studi yang lain dalam membina kedisiplinan dan minat belajar siswa.

- Sebagai bahan pertimbangan bagi peneliti berikutnya, yang berminat melakukan penelitian sejenis.

\section{DAFTAR PUSTAKA}

Abdullah Nashih Ulwan, Tarbiyat alAulad fi al-Islam, diterjemahkan oleh : Drs.

Jamaluddin Miri, Lc dengan judul Pendidikan Anak dalam Islam, Jakarta

Pustaka Amani, 2002.

Akhyak, Profil Pendidik Sukses: Sebuah Formulasi dalam Implementasi

Kurikulum Berbasis Kompetesis, Surabaya: Elkaf, 2005.

Arman Arief, Pengantar Ilmu dan Metodelogi Pendidikan Islam, Jakarta: Ciputat Pers, 2002. 
A. Tabrani, Cece Wijaya. “ Kemampuan Dasar Dalam proses Belajar Mengajar", Bandung: PT. Remaja Rosda Karya, 1994.

A. Toto Suryana, PendidikanAgama Islam, Cet. I; Bandung: Tiga Mutiara, 1997.

Azwar Syaifuddin, Tes Prestasi Fungsi dan Pengembangan Pengukuran Prestasi

Belajar, Yogyakarta: Pustaka Pelajar, 2015.

Danim, Sudarwan, Profesionalisasi dan Etika Profesi Guru. Bandung: Alfabeta.2010.

Departemen Pendidikan Nasional.

Kamus Besar Bahasa Indonesia.

Jakarta: Balai Pustaka, 2008.

Djamarah, Syaiful Bahri dan Aswan

Zain, Strategi Belajar Mengajar,

Jakarta:

Rineka Cipta. 2010.

Hamalik, Oemar, Pendidikan Guru

Berdasarkan Pendekatan

Kompetensi, Jakarta: Bumi

Aksara. 2002.

Hasibuan, J.J., dan Moedjiono, Proses

Belajar Mengajar, Bandung:

Rosdakarya. 2010.

Indra Ahmad Wijaya, Guru dan

Orangtua Sebagai Pendidik,

Jakarta: Cita Pustaka. 2000.
Kunandar, Guru Profesional Implementasi Kurikulum Tingkat Satua Pendidikan (KTSP) dan Sukses Dalam Sertifikasi Guru, Jakarta: Rajawali Pers. 2009.

Koiron Rosyadi, Pendidikan Propetik, Yogyakarta: Pustaka Pelajar Offset, 2004.

Muhammad Ali. Guru dalam proses belajar mengajar. Bandung: Sinar Baru

Algensindo, 2004.

M. Athiyah Al-Abrasyi, Dasar-dasar Pokok Pokok Pendidikan Islam, terj. Bustami A. Ghani dan Djohar Bahry, Jakarta: Bulan Bintang, 1987.

Muhammad Fadlillah \& Lilif Mualifatu Khorida, Pendidikan Karakter Anak Usia Dini, Yogyakarta: Ar-Ruzz Media, 2013.

Naim, Ngainun, Menjadi Guru Inspiratif: Membedayakan dan Mengubah Jalan

Hidup Siswa, Yogyakarta Pustaka Pelajar, 2009.

Nurdin, Syafruddin, Guru Profesional dan Implementasi Kurikulum, Jakarta:

Ciputat Pers, 2002. 
Omar Muhammad Al-Toumy AsSyaibani, Falsafah Pendidikan

Islam, Jakarta: Bulan Bintang, 1979.

Paul Suparno, Guru Demokratis di Era

Demokrasi, Yogyakarta:

Grasindo, 2005.

Pandji Anoraga, Psikologi Kerja, Jakarta: Rineka Cipta, 2006.

Rahman Muhammad, Sofan Amri, Kode Etik Profesi Guru, Jakarta:

Prestasi Pustaka, 2014.

Ranopandojo dan Husnan, Manajemen

Personalia, Yogyakarta: BFFE, 1984.

Sa'id, Imam Ghazali, Silsilat AlMuallifat al-Ghazali (2) Matnu Bidayat Al Hidayah fi AtTawassuth Bainal Fiqh wa Tasawuf lil Iman Hujjatul Islam

Abi Hamid al-Ghazali , Surabaya:

Diyantara, T.Th, 1985

Sabri, Alisuf. Psikologi Pendidikan. Jakarta: Pedoman Ilmu Jaya, 2007.
Sardiman, Interkasi dan Motivasi Belajar Mengajar, Jakarta: Raja Grapindo Persada, 2007.

Singgih D. Gunarsa, Psikologi Perkembangan Anak dan Remaja, Jakarta: Gunung Mulia, 2006.

Slameto, Belajar dan Faktor-Faktor Yang mempengaruhinya. Jakarta: Rineka Cipta. 2003.

Sugiyono, Metode Penelitian Pendidikan (Pendekatan Kuantitatif, Kualitatif, dan R \& D), Bandung: Alvabeta, 2015.

Sumadi Suryabrata. Psikologi pendidikan, Jakarta: Raja Grafindo Persada, 2002.

Suparlan, Menjadi Guru Efektif, Yogyakarta: Hikayat, 2005.

Suwarno, Wiji, Dasar-dasar Ilmu Pendidikan, Yogyakarta: ArRuzz Media, 2009.

S. Nasution. Berbagai Pendekatan Dalam Proses Belajar Mengajar, Jakarta: Pt Bumi Aksara, 2000.

Tobroni, Pendidikan Islam Paradigma Teologis Filosofis dan Spritualitas, Malang: UMM Pers. 2008. 
